\title{
FLEXIBLLITY PROGRAM AMONG LOWER SECONDARY SCHOOL STUDENTS AMD PHYSICAL FITMESS INDICATORS ASSESSED IN THE CONVENTION OF HEALTH-RELATED FITNESS (H-RF)
}

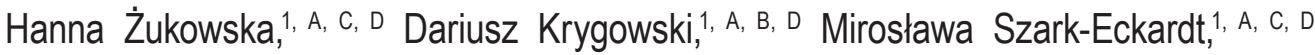 \\ Magdalena Zając ${ }^{2, A, C, ~ D ~}$
}

1 Faculty of Physical Education, Health and Tourism, Kazimierz Wielki University in Bydgoszcz, Poland

${ }^{2}$ Faculty of Pedagogy and Psychology Kazimierz Wielki University in Bydgoszcz, Poland

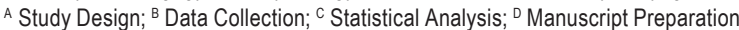

\author{
Address for correspondence: \\ Hanna Żukowska \\ Faculty of Physical Education, Health and Tourism, Kazimierz Wielki University in Bydgoszcz, Poland \\ Sportowa 2, 85-091 Bydgoszcz, Poland \\ E-mail: Żukowska@ukw.edu.pl
}

Ahstract Flexibility is one of the elements - components which support physical fitness and health as well (Howley, Franks, 1997; Bouchard, Shephard, 1994; Skinner, Oja, 1994). The purpose of this paper was to assess the impact of additional flexibility exercises on physical fitness in lower secondary school students, evaluated by means of IPFT (the International Physical Fitness Test). The study was conducted in two experimental groups, where extra flexibility exercises were added to all obligatory PE lessons, and one control group.

1. The decreased standard deviation observed in particular IPFT attempts in the experimental class is the correct tendency showing the favorable influence of flexibility exercises on students' physical fitness and health.

2. An improvement and considerably better, though statistically insignificant, results were obtained by the students involved in the additional exercises, in all assessed motor skills (strength, speed, endurance and flexibility) and in the scoring reflecting the level of physical fitness.

3. After one year of exercises the control group had worse average results in two attempts $-50 \mathrm{~m}$ run (to assess speed) and standing forward bend (to measure flexibility). This trend indicates the importance of flexibility exercises as regards speed and agility.

Key WOrdls flexibility, physical fitness, health, IPFT (the International Physical Fitness Test), students

\section{Introduction}

Physical fitness is one of the main health indicators and belongs to the characteristics which are frequently assessed by specialists from different fields. Over the past few years physical fitness has been contrasted with motor performance or skill-related components - or rather distinguished from them (Osiński, 2009). Howley, Franks (1997) present physical fitness as the purpose of positive health „which determines the low risk of health problems”. 
As Osiński reports (2003) the assessment of track record in sport used to be the aim of testing the level of physical fitness, yet only in the 1980s there were introduced "the elements of physical fitness characteristics intended to (...) provide information on health". The author emphasizes that physical fitness testing facilitates the identification of one's own body needs and the development of health and care for one's own body. According to the healthrelated fitness $(\mathrm{H}-\mathrm{RF})$, the testing of physical fitness is mainly expected to serve for the purposes of diagnosis and a wide-range support to health patterns and not to refer to the actual level of motor performance (Osiński, 2003; 2009). Health-related fitness consists of such components as body composition, cardiovascular endurance, muscular endurance and muscular strength as well as flexibility (Bouchard, Shephard, 1994; Howley, Franks, 1997; Skinner, Oja, 1994; Osiński, 2009). Flexibility is essential for maintaining a good body posture, a certain level of fitness particularly during old age (Osiński, 2009). Well-developed flexibility ensures that an individual can make a movement in a fast, economic and technically proper way; what is more, it can be developed by every man at every moment of life to achieve a high level indeed. Nevertheless, the best time to shape flexibility is childhood because just then the body becomes most susceptible to stimulation of flexibility development (Marciniak, 1998). The available literature provides a large number of references with strong indications of the links between physical activity, fitness, efficiency and health. Yet, these indicators, defined as the so called positive health measurements, are not used in medical diagnostics (Drabik, 2006).

Aiming at their improvement is becoming the subject of research (Bendikovà, Šmída, Rozim, 2014; Łubkowska, Troszczyński, 2011; Kostencka, et al., 2004; Przewęda, Dobosz, 2003) and a strategy of numerous countries (Bendikovà et al., 2014; Bendikova, Uvinha, Pines, Kanásová, Šmída, 2015; Bendíková, Kostencka, 2013; Rado, Dervišević, Kovač, Ćirić, 2015).

The purpose of this study was to determine the influence of the flexibility program on physical fitness in boys at lower secondary school age.

\section{Material and methods}

The study was carried out in five stages:

- the first stage included the choice of a lower secondary school and the classes at the same education level, taught by the same teacher of physical education. Then two groups were selected from among the classes - the experimental group and the control one,

- the second stage involved the somatic development assessment based on the measurement of body height and weight, as well as the body mass index,

- the third stage was the assessment of the physical fitness level on the basis of the IPFT (Drabik, 2006),

- the flexibility program was introduced during the fourth stage,

- the reassessment of the physical fitness level took place in the fifth stage.

The study was conducted in the Lower Secondary School No. 1 in Tuchola and the experimental group (class 1B) and the control group (class 1D) were selected as a result of random sampling. The study group consisted of boys with the same conditions to take up compulsory physical activity - physical education lessons. Both classes attended four lessons under the core physical education curriculum on a weekly basis and the lessons were given by the same teacher.

Then the somatic development assessment was performed to verify if this development was at the similar level (if there were any significant differences in body height, weight and body mass index) (Table 1). The following 
step was the physical fitness assessment based on the IPFT followed by introducing the additional 15-minute flexibility program to compulsory physical education lessons in the experimental group. Finally, physical fitness was reassessed in order to determine the impact of the extra flexibility program on the results achieved in subsequent physical fitness attempts. Each stage of physical fitness testing was conducted in accordance with the methodology (Drabik, 2006).

The experimental group (class 1B) consisted of 15 boys whereas the control group (class 1D) of 18 individuals.

The fitness attempts were performed in the gymnasium, at the Orlik pitch and sports stadium. The students involved in the study performed the fitness test in sportswear after a warm-up.

The physical fitness test was made up of 8 attempts: 50 m run (to measure speed), standing long jump (to measure the jumping ability/ explosive power of the lower limbs), $1000 \mathrm{~m}$ run (to measure endurance), handgrip test (to measure hand strength) ${ }^{1}$, flexed arm hang (to measure relative strength), $4 \times 10$ m shuttle running test (to assess agility), $30 \mathrm{~s}$ sit-and-reach (to measure abdominal muscle strength), trunk flexion (to measure flexibility) (Drabik, 2006).

\section{Flexibility exercise program}

The flexibility program was based on "The battery of correctional and flexibility exercises" by J. Marciniak (1998, pp. 66-94) and included the set of the exercises mentioned below.

1. The upper limb and pelvic girdle exercises:

a) starting position: standing with legs spread apart. Step aside with your right leg and simultaneously swing your arms in opposite directions. After 10 swinging exercises change your leg and perform the same battery with your left leg;

b) starting position: standing with legs spread far apart. Arm rotation forwards for 10 seconds, then backwards for another 10 seconds;

c) starting position: stand with arms straight forward, then rest your right wrist on the left elbow and pull behind your head, next return to the starting position and repeat with the other arm. Do this exercise 5 times on each side.

2. Lower limb exercises:

a) starting position: standing with your legs slightly spread apart and your knees bent, make the swinging movement to the left and then to the right; exercise for 10 seconds to each direction;

b) starting position: standing. Swing your right leg forward and up to your left arm straight ahead and repeat the exercise with the other leg. Do this exercises 10 times on each leg;

c) lie back, keep your arms straight along your trunk, knees bent at ca. 90 degrees. Swing your legs alternately forward up and down. Swing each leg up 10 times.

3. Trunk exercises:

a) starting position: standing position with your legs together and arms at side. Lean forward and simultaneously swing your arms backward, return to the starting position Leanie backward. Repeat the exercise 10 times;

b) stand with your legs apart, raise your arms and grip your elbows. Keeping this position lean forward and return to the starting position. Do this exercise 10 times; 
c) lie on your stomach. Pull your trunk maximally backward with your shoulders and simultaneously pull your head back.

\section{Compilation of statistical material}

The collected material was subject to the statistical analysis using the basic methods of descriptive statistics (arithmetic mean, standard deviation). The formulated hypotheses about the significance of differences in average deviations for particular tests were verified by means of statistical tests: for two average values (Student's t-test for independent variables), Student's t-test for differences between the correlated pairs of measurements. The analysis of the correlations between the measurements was carried out using the Pearson's linear correlation coefficient.

\section{Results}

Below there is presented the evaluation of the significance of differences and the comparison of the average results achieved by the subjects: between the experimental group (1b) and the control group (1d) in the study conducted in autumn and spring (Table 1), between the results produced by the individual groups in the study in autumn and spring - the experimental group (class 1b) Table 2, the control group (class 1d) Table 3.

Table 1. Statistical characteristics of the significance of differences, the results achieved in the particular IPFT tests, between the experimental group (1b) and the control group (1d) in the study conducted in autumn and spring

\begin{tabular}{|c|c|c|c|c|c|c|}
\hline \multirow{3}{*}{ IPFT } & \multicolumn{2}{|c|}{ Analyzed groups } & \multirow{3}{*}{$\mathrm{T}$} & \multirow{3}{*}{$\mathrm{p}$} & \multirow{2}{*}{$1 \mathrm{~b}$} & \multirow{2}{*}{$1 d$} \\
\hline & $1 \mathrm{~b}$ & $1 d$ & & & & \\
\hline & $\bar{x}$ & $\bar{x}$ & & & SD & SD \\
\hline $50 \mathrm{~m}$ run - autumn & 8.2867 & 8.2833 & 0.01111 & 0.991209 & 0.95608 & 0.76869 \\
\hline $50 \mathrm{~m}$ run - spring & 8.2733 & 8.6111 & -1.16925 & 0.251217 & 0.71261 & 0.90936 \\
\hline Standing long jump - autumn & 158.2667 & 170.8333 & -1.33628 & 0.191184 & 29.10196 & 24.94052 \\
\hline Standing long jump - spring & 163.6000 & 175.6111 & -1.18346 & 0.245623 & 27.22079 & 30.44018 \\
\hline $1000 \mathrm{~m}$ run - autumn & 313.6000 & 302.2778 & 0.61900 & 0.540437 & 57.68114 & 47.45128 \\
\hline $1000 \mathrm{~m}$ run - spring & 297.5333 & 287.6667 & 0.53970 & 0.593261 & 58.83739 & 46.21306 \\
\hline Hand strength - autumn & 13.0667 & 12.4444 & 0.46335 & 0.646347 & 3.99046 & 3.71360 \\
\hline Hand strength - spring & 14.4000 & 13.8333 & 0.39802 & 0.693340 & 3.75690 & 4.31482 \\
\hline Flexed arm hang - autumn & 16.0340 & 10.6500 & 1.22825 & 0.228597 & 15.11431 & 9.92734 \\
\hline Flexed arm hang - spring & 21.1800 & 12.9944 & 1.55434 & 0.130255 & 18.31862 & 11.72285 \\
\hline $4 \times 10 \mathrm{~m}$ shuttle running test - autumn & 12.5000 & 12.1778 & 1.01126 & 0.319720 & 1.11484 & 0.70089 \\
\hline $4 \times 10 \mathrm{~m}$ shuttle running test - spring & 11.7400 & 11.3778 & 1.31972 & 0.196591 & 0.88221 & 0.69499 \\
\hline Sit-and-reach - autumn & 21.0000 & 25.0556 & -3.30922 & 0.002379 & 3.33809 & 3.63759 \\
\hline Sit-and-reach - spring & 22.2667 & 25.7778 & -2.37135 & 0.024118 & 3.36933 & 4.83316 \\
\hline Trunk flexion - autumn & -0.9333 & 2.0000 & -0.96679 & 0.341134 & 11.16414 & 5.89117 \\
\hline Trunk flexion - spring & 2.0667 & 1.4444 & 0.20427 & 0.839477 & 10.84611 & 6.44636 \\
\hline Physical fitness level (score) - autumn & 328.1333 & 341.8333 & -0.56983 & 0.572898 & 83.43335 & 53.77103 \\
\hline Physical fitness level (score) - spring & 341.6000 & 351.6111 & -0.39900 & 0.692630 & 82.10168 & 61.97926 \\
\hline
\end{tabular}

When analyzing the results achieved in the particular IPFT attempts by the experimental group (1b) and the control group (1d), some slight differences can be observed in the average results revealed in the tests between 
both groups in autumn and spring alike. The only significant difference between both groups was reported in the sit-and-reach test. Significantly better results were produced by the students from the control group (1d) in autumn and spring as well.

Table 2 outlines the differences in the average results achieved in the individual physical fitness tests by the experimental group (1b) at the onset of the experiment (autumn) and the end (spring).

Tahle 2. Statistical characteristics of the significance of differences concerning the results achieved in the individual IPFT attempts in the experimental group (1b) at the onset of the experiment (autumn) and at the end (spring)

\begin{tabular}{|c|c|c|c|c|}
\hline \multicolumn{5}{|c|}{ Class $1 \mathrm{~b}$} \\
\hline \multirow{2}{*}{ IPFT } & \multicolumn{2}{|c|}{ Period of test } & \multirow{2}{*}{$t$} & \multirow{2}{*}{ p } \\
\hline & autumn & spring & & \\
\hline $50 \mathrm{~m}$ run & 8.286667 & 8.273333 & 0.043306 & 0.965765 \\
\hline Standing long jump & 158.266700 & 163.600000 & 0.518362 & 0.608278 \\
\hline $1000 \mathrm{~m}$ run & 313.600000 & 297.533300 & 0.755214 & 0.456427 \\
\hline Hand strength & 13.066670 & 14.400000 & 0.942211 & 0.354144 \\
\hline Flexed arm hang & 16.034000 & 21.180000 & 0.839210 & 0.408460 \\
\hline $4 \times 10 \mathrm{~m}$ shuttle running test & 12.500000 & 11.740000 & 2.070431 & 0.047747 \\
\hline Sit-and-reach & 21.000000 & 22.266670 & 1.034340 & 0.309829 \\
\hline Trunk flexion & -0.933333 & 2.066667 & 0.746469 & 0.461607 \\
\hline Physical fitness level (score) & 328.133300 & 341.600000 & 0.445571 & 0.659333 \\
\hline
\end{tabular}

The analysis of the average results achieved in the particular IPFT attempts at the beginning and the end of the experiment showed some improvement in all results achieved, yet the results turned out to be insignificant. However, a significant improvement was observed in the trunk flexion test.

Table 3 presents the differences in the average results achieved in the physical fitness tests in the control group (1d) at the onset of the experiment (autumn) and at the end (spring).

Tahle 3. Statistical characteristics of the significance of differences concerning the results achieved in the particular IPFT attempts in the control group (1d) at the onset of the experiment (autumn) and at the end (spring)

\begin{tabular}{|c|c|c|c|c|}
\hline \multicolumn{5}{|c|}{ Class 1d } \\
\hline \multirow{2}{*}{ MTSF } & \multicolumn{2}{|c|}{ Period of test } & \multirow{2}{*}{$t$} & \multirow{2}{*}{$\mathrm{p}$} \\
\hline & autumn & spring & & \\
\hline $50 \mathrm{~m}$ run & 8.283333 & 8.611111 & -1.16790 & 0.250971 \\
\hline Standing long jump & 170.833300 & 175.611100 & 0.515096 & 0.609819 \\
\hline $1000 \mathrm{~m}$ run & 302.277800 & 287.666700 & 0.935884 & 0.355933 \\
\hline Hand strength & 12.444440 & 13.833330 & 1.03508 & 0.307937 \\
\hline Flexed arm hang & 10.650000 & 12.994440 & 0.647502 & 0.521656 \\
\hline $4 \times 10 \mathrm{~m}$ shuttle running test & 12.177780 & 11.377780 & 3.438677 & 0.001563 \\
\hline Sit-and-reach & 25.055560 & 25.777780 & 0.506544 & 0.615744 \\
\hline Trunk flexion & 2.000000 & 1.444444 & -0.269905 & 0.788865 \\
\hline Physical fitness level (score) & 341.833300 & 351.611100 & 0.505569 & 0.616422 \\
\hline
\end{tabular}


The analysis of the average results achieved in the particular IPFT attempts at the beginning and the end of the experiment revealed a slight improvement in six out of eight results achieved. The subjects got worse results in the second session of tests (spring) in two tests, namely, in the $4 \times 10 \mathrm{~m}$ shuttle running test and the trunk flexion test.

Table 4 shows the difference between the results achieved in autumn and spring, and the difference is presented as the numerical indicator; next, the significance of the average values of the changes in both groups is assessed.

Table 4. The assessment of the statistical significance of the results of the differences between the tests conducted in autumn and spring in the IPFT attempts, between the experimental group (1b) and the control group (1d)

\begin{tabular}{|c|c|c|c|c|}
\hline \multirow{3}{*}{ IPFT } & \multicolumn{2}{|c|}{ GROUP } & \multirow{3}{*}{$t$} & \multirow{3}{*}{$p$} \\
\hline & \multirow{2}{*}{$\begin{array}{c}\text { experimental } 1 \mathrm{~b} \\
\text { difference between the average results } \\
\text { (autumn/spring) }\end{array}$} & \multirow{2}{*}{$\begin{array}{l}\text { control 1d } \\
\text { difference between the average results } \\
\text { (autumn/spring) }\end{array}$} & & \\
\hline & & & & \\
\hline $50 \mathrm{~m}$ run & 0.0133 & -0.32778 & 1.41434 & 0.167227 \\
\hline Standing long jump & 5.3333 & 4.77778 & -0.10036 & 0.920706 \\
\hline $1000 \mathrm{~m}$ run & 16.0667 & 14.61111 & 0.18469 & 0.854673 \\
\hline Hand strength & 1.3333 & 1.38889 & 0.06639 & 0.947494 \\
\hline Flexed arm hang & 5.1460 & 2.34444 & -0.94100 & 0.353981 \\
\hline $4 \times 10$ m shuttle running & 0.7600 & 0.80000 & -0.19589 & 0.845977 \\
\hline Sit-and-reach & 1.2667 & 0.72222 & -0.41788 & 0.678916 \\
\hline Trunk flexion & 3.0000 & -0.55556 & -1.61167 & 0.117169 \\
\hline Physical fitness level (score) & 13.4667 & 9.77778 & -0.35885 & 0.722141 \\
\hline
\end{tabular}

The analysis of the figures outlined in Table 4 clearly shows that the experimental group (class $1 \mathrm{~b}$ ) had a substantial improvement in most of the IPFT tests assessed, although no significant differences were observed. On the opposite, the control group, not involved in the additional flexibility exercises, was reported to have a slightly improved results in six out of eight tests and even worse results in two tests (trunk flexion and $50 \mathrm{~m}$ run). Likewise, the average score determining the physical fitness level of the subjects was better in the case of the experimental group.

Table 5 outlines the difference between two correlation coefficients.

Table 5. The difference between two correlation coefficients in the evaluation of the trunk flexion test performed in autumn and spring

\begin{tabular}{cc}
\hline Experimental group 1b (The marked correlation coefficients are significant with $p<0.05000)$ \\
\hline Trunk flexion - autumn & Trunk flexion - spring \\
Control group 1d (The marked correlation coefficients are significant with $p<0.05000)$ \\
\hline Trunk flexion - autumn & Trunk flexion - spring \\
& 0.4223 \\
& $p=0.0061$ \\
\hline
\end{tabular}


The difference between two correlation coefficients is statistically significant at the level of $p<0.0479$. In the experimental group $1 \mathrm{~b}$ there is a closer correlation between the results of both measurements whereas in the control group this correlation is much weaker (this means that in the experimental group those who are fitter maintain their fitness, but in the control group, more commonly, some individuals considerably improve their results while others get worse results.

\section{Summary}

Health is the most important value. When taking physiology into consideration, health also means the efficiency of adaptive mechanisms and adaptability comprises the basis of health (Drabik, 2006). Therefore, physical fitness, activity and efficiency can be considered as the adaptive elements, thus, they are health components (Drabik, 2006). In the light of the above, it is apparent that health does not just mean the absence of disease but it is also wellbeing. Hence, one should not only focus on the fight against disease, but in the first place on aiming at being healthy and maintaining good health. That is why, it is also essential to control the positive health measurements, such as the quality of life, life expectancy, physical activity, physical development and physical fitness (Hyder, Morrow, 2006; Drabik, 2006; Karski, 1997). Controlling physical fitness, including especially the components connected with cardiopulmonary system, motor skills as well as flexibility provide the image of the health of the body (Bouchard, Shephard, 1994; Drabik, 2006), (Howley, Franks, 1997; Osiński, 2003). Thus, flexibility is an important component of physical fitness and of health as well. As Osiński reports (2003), appropriate flexibility may protect from the musculosceletal injuries whereas the absence of proper flexibility may cause diseases and dysfunctions of the motor system.

This study assessed the impact of the additional flexibility program as an important factor determining wellbeing, on physical fitness in the boys. After the experiment was completed, a substantial improvement was achieved in all IPFT attempts and the standard deviation was reduced which shows that regular flexibility exercises positively influence the evaluated components of physical fitness. As Drabik claims (2006), parents should be acquainted with the students' physical fitness level as it is conducive to teaching health-related behavioral patterns and values and developing in parents a conscious attitude to exercise in general. Physical activity is an essential determinant of staying healthy and also serves as a means in the health education of the society (Paczyńska-Jędrycka, Łubkowska, 2014):

1. Introducing the 15-minute flexibility program to physical education lessons is insufficient to achieve significant differences in the physical fitness level.

2. The decreased standard deviation in the individual IPFT attempts in the experimental class, to which the additional flexibility exercises were introduced (as opposed to the control group, where the standard deviation increased after one year of exercises) is a normal tendency and shows a positive influence of the flexibility exercises on physical fitness and so on the health of the students.

3. The students engaged in the additional exercises had an improvement and considerably better, though not statistically significant, results in all assessed motor skills (strength, speed, endurance and flexibility) as well as in the score-based assessment reflecting physical fitness.

4. Following one year of exercises, the students not involved in the extra flexibility exercises got worse average results in two tests $-50 \mathrm{~m}$ run (to measure speed) and trunk flexion (to evaluate flexibility). This tendency suggests the special meaning of flexibility exercises for speed and flexibility. 


\section{References}

Bendíková, E., Kostencka, A. (2013). Exercise routine as a Conditions of early school age pupils' health. Bydgoszcz: Oficyna Wydawnicza Mirosław Wrocławski.

Bendikovà, E., Šmída, L., Rozim, R. (2014). Level of posture of pupils in the age of elementary schools. European Res., 75 (5-2), 990-996.

Bendikova, E., Uvinha, R.R., Pines, A.R., Kanásová, J., Šmída, L. (2015). The influence of exercise program on the muscular system of female pupils in the lessons of physical education and sport. Sport Sci., 8 (2), 69-74.

Bouchard, C., Shephard, R.J. (1994). Physical activity, fitness, and health: The model and key concepts. In: C. Bouchard, R.J. Shephard, T. Stephens T. (eds.), Physical Activity. Fitness Health (pp. 77-88). Champaing: Human Kinetics.

Drabik, J. (2006). Pedagogiczna kontrola pozytywnych mierników zdrowia fizycznego. Gdańsk: AWFiS.

Howley, E.T., Franks, B.D. (1997). Health Fitness Instructor's. Handbook. Champaing: Human Knetics Publishers.

Hyder, A.A., Morrow, R.H. (2006). Measures of Health and Disease in Populations. In: M.H. Merson, R.E. Black, A. Mills (eds.), International Public Health: Diseases, Programs, Systems, and Policies (pp. 1-42). Sudbury: Jones \& Bartlett.

Kostencka, A., Kostencki, A., Jeka, S., Czarny, W., Czaja, R., Bożiłow, W. (2004). Badanie zależności między sprawnością fizyczną a wybranymi cechami somatycznymi chłopców w wieku 13-16 lat. In: J. Zagórski, H. Popławska, M. Skład. (eds.), Uwarunkowania rozwoju dzieci i młodzieży wiejskiej (pp. 692-697). Lublin: Instytut Medycyny Wsi.

Łubkowska, W., Troszczyński, J. (2011). Próba weryfikacji aktywności ruchowej jako kryterium oceny postawy ciała dziewcząt i chłopców w wieku 7-15 lat. Zeszyty Naukowe Uniwersytetu Szczecińskiego. Prace Instytutu Kultury Fizycznej, 631 (27), $27-40$.

Marciniak, J. (1998). Zbiór ćwiczeń koordynacyjnych i gibkościowych. Warszawa: Centralny Ośrodek Sportu.

Osiński, W. (2003). Antropomotoryka. Poznań: AWF.

Osiński, W. (2009). Metody diagnostyczno-ewaluacyjne. In: S. Kowalik (ed.), Kultura fizyczna osób z niepełnosprawnością (pp. 151194). Gdańsk: GWP.

Paczyńska-Jędrycka, M., Łubkowska, W., Edukacja zdrowotna przez gry i zabawy ruchowe z uwzględnieniem zabaw animacyjnych w opinii studentek pedagogiki elementarnej (na przykładzie województwa wielkopolskiego). Pielęg. Pol., 3 (53), $215-221$.

Rado, I., Dervišević, E., Kovač, S., Ćirić, A. (2015). Analysis of posture status diversity between girls and boys, aged 7-9 years, recorded in three dimensions. Sport Sci., 8 (1), 83-87.

Skinner, J.S., Oja, P. (1994). Laboratory and field tests for assessing health-related fitness. In: C. Bouchard, S.T. Shephard, T. Stephens (eds.), Physical Activity, Fitness Health (pp. 160-179). Champaing: Human Kinetics.

Cite this article aS: Żukowska, H., Krygowski, D., Szark-Eckardt, M., Zając, M. (2016). Flexibility Program among Lower Secondary School Students and Physical Fitness Indicators Assessed in the Convention of Health-related Fitness (H-RF). Central European Journal of Sport Sciences and Medicine, 15 (3), 55-62. DOI: 10.18276/cej.2016.3-06. 